\title{
The Effect of Lease Accounting on Credit Rating and Cost of Debt: Evidence from Firms in Korea
}

\author{
Younghee Park ${ }^{1}$ and Kyunga $\mathrm{Na}^{2, *}$ \\ 1 School of Smart Business, Yeungjin University, 35, Bokhyeon-ro, Buk-gu, Dalseo-gu, Daegu 702-721, Korea; \\ younghee1110@nate.com \\ 2 Department of Accounting and Taxation, Keimyung University, Euiyang Hall 327, 1095, Dalgubeol-daero, \\ Dalseo-gu, Daegu 704-701, Korea \\ * Correspondence: kyunga@kmu.ac.kr; Tel.: +82-53-580-6396
}

Received: 30 July 2018; Accepted: 4 September 2018; Published: 7 September 2018

check for updates

\begin{abstract}
This study examines the effect of capital lease and operating lease options in accounting on credit ratings and the cost of debt using data for 13 years (2001 to 2013) on 6133 listed and unlisted domestic firms in Korea that recognize leases on financial statements. We use the Heckman two-stage model to control for sample selection bias from lease selection. The first stage is the probit regression in which the dependent variable is a dummy variable on the lease selection and the explanatory variables are factors known to affect lease selection. The second stage consists of the ordered probit regression model and the ordinary least square regression model where the dependent variables are credit rating and cost of debt, respectively. The results show that lease selection does not significantly affect corporate credit ratings-however, in terms of the cost of debt, enterprises that adopt operating leases spend considerably less than firms that engage in capital leases. Further analysis suggests that the results for credit ratings do not differ by listing status. However, the cost of debt for listed companies does not seem to differ by lease selection, while unlisted firms see a sharp decline in their cost of debt when they choose operating leases over capital leases.
\end{abstract}

Keywords: lease; operating lease; finance lease; listed firms; unlisted firms; cost of debt

\section{Introduction}

A lease is a transaction whereby a lessor transfers the right to use a leased asset to a lessee for an agreed period of time (lease term). Under contractual agreement, the lessee makes lease payments to the lessor for the use of the asset. Unlike other transactions, which call for the seller to hand over the legal ownership of certain goods or services to the client, as well as all incidental rights and benefits, the legal ownership of a lease asset stays with the lessor during the lease term; the lessee only holds the right to use the underlying asset. From the lessee's perspective, leasing an asset and borrowing money to purchase the asset are similar in practical economic aspects, yet they prefer the former option because it reduces the burden of purchasing through borrowing and lowers the risk of intangibles such as possible obsolescence.

For accounting purposes, there are two types of lease transactions: capital leases and operating leases. The former refers to an accounting transaction similar to a purchase against a loan, thereby transferring the risks and rewards resulting from the ownership of the leased asset to the lessee. Therefore, the lessee needs to record the lease assets and lease liabilities and recognize the principal repayments and interest expenses of the capital lease liability. The latter is an accounting item where risks and rewards incidental to the ownership of a lease asset stay with the lessor, so the lessee treats the fixed lease payments as a cost of business in the income statement. Thus, recording an operating 
lease does not increase liabilities, creating an off-balance-sheet effect without increasing the company's debt-equity ratio.

Recognizing similar lease transactions as different accounting items, however, can undermine the comparability between companies that use leases. In addition, there is a strong possibility that business managers' discretion can affect lease selection for accounting and the terms and conditions on the contract can be modified arbitrarily. Because of these issues, the International Accounting Standards Board (IASB) released an exposure draft in 2010 to unify all types of leases to capital leases for accounting. The third exposure draft has been published and accounting for leases is scheduled for revision based on the exposure drafts beginning 2019. ${ }^{1}$

Previous research on lease accounting focuses on the determinants of a firm's lease selection. Some prior studies insist that companies with a higher ratio of debt are incentivized to adopt operating leases to prevent a rise in the debt-equity ratio (McGregor 1996; Lee 1999; Chung 2000; Yoon and Hong 2001). Firms are generally wary of an increase in their debt-equity ratio because a higher ratio could lead to lower corporate credit ratings (Jeon and Lee 2015) and a rise in the cost of debt (Park et al. 2012; Park and Kim 2013; Park and Nam 2013). In this respect, the effect of lease type on credit ratings and costs of debt may be important but little research is available on this topic. To fill this gap, we raise the first two research questions as follows; whether adopting an operating lease over a capital lease (1) improves credit ratings and (2) lowers the costs of debt financing.

Companies may have different ownership and financial structures depending on their listing status and these distinctions may lead to differences in the type of lease that companies recognize for accounting (Park and Na 2017). In terms of ownership structure, shares of listed companies are distributed among numerous shareholders and traded in the open market, putting these firms under capital market pressure. In particular, companies must comply with regulations regarding the disclosure of financial information to investors in the capital market. In contrast, a large percentage of unlisted firms are owner-managed and family-run (Chaney et al. 2004), with shares held by a small number of major shareholders and not traded in the open market. Consequently, compared to listed companies, unlisted firms experience less pressure from the capital market and need not comply with disclosure regulations (Hope et al. 2013) and thus tend to report lower-quality financial information. From the perspective of financial structure, listed firms are capable of raising capital from general investors by issuing stocks and bonds in the stock and debt markets, respectively. Unlisted companies, however, cannot attract capital by issuing stocks in the capital market and have to raise the necessary funds mostly through private loans (Kim et al. 2011). Thus, unlisted firms are more dependent on private debt and have less financial stability than their listed counterparts do. They may be therefore reluctant to adopt accounting practices that increase debt, consequently favoring operating leases, which offer the off-balance-sheet effect (Park and Na 2017). In other words, a company's listing status can affect its choice of lease.

Since the lease accounting choice, disclosure quality, financial structure, as well as the characteristics of debt can be different between the listed firms and the unlisted firms, the listing status may influence the relation between lease selection and credit rating or that between lease selection and cost of debts. These questions are addressed in Hypotheses 3 and 4. Although it would be normally difficult to collect financial data of unlisted firms in many countries including the US, the KIS VALUE database provides financial information on both listed and unlisted firms in Korea, which enables us to pursue these questions.

This study provides several findings. First, companies' choice of lease does not affect their credit ratings, which implies that when credit rating agencies conduct company assessments, they do not regard operating lease recognition as being different from capital lease recognition. Furthermore, lease selection does not seem to have a significant impact on credit ratings for both listed and unlisted companies. Listing status may not affect crediting rating because the same credit rating agencies

1 The Korea Accounting Institute (http:/ / www.kasb.or.kr). 
evaluate both listed and unlisted companies, that is, the firms will be evaluated using the same metric regardless of their listing status. On the other hand, firms could lower their costs of debt significantly by choosing an operating lease over a capital lease, which implies that unlike credit rating agencies, creditors do care about the type of lease when evaluating a borrower-specifically for unlisted firms, creditors impose lower interest on those choosing operating lease. The effect on the cost of debt may be due to the gaps between listed and unlisted firms in terms of the quality of disclosed financial information. Compared to unlisted firms, listed firms tend to have higher quality information, which would allow creditors to evaluate listed firms more accurately and provide appropriate cost of debt, regardless of the lease type. In contrast, as unlisted firms may provide lower-quality information, users of operating leases may appear to have less debt and therefore be more attractive to creditors than those of capital leases, leading to a lower cost of debt for the former.

Our findings contribute to the current accounting research as the first study to provide empirical evidence on the effect of lease accounting on credit rating and cost of debts. Our results are especially important to potential creditors who are interested in investing in unlisted firms, as the use of operating lease may distort the financial structures of these firms and convince the creditors to impose a lower interest rate.

This paper proceeds as follows. Section 2 reviews the previous research and develops the hypotheses. Section 3 describes the sample selection and research design and Section 4 presents the empirical analysis. Section 5 presents our conclusions.

\section{Literature Review and Hypothesis Development}

One of the biggest reasons a firm may choose operating leases over capital leases would be that the former does not increase the firm's debt-equity ratio. Companies with a higher debt-equity ratio are perceived to have a greater risk of default or bankruptcy, so they face higher costs of debt (Park et al. 2012; Park and Kim 2013; Park and Nam 2013). A higher debt-equity ratio is also likely to lower the corporate credit ratings (Jeon and Lee 2015) and, in turn, increase the borrowing interest rates (Park et al. 2013). Such outcomes incentivize firms to lower their debt-equity ratio and improve financial structure and one method is choosing operating leases over capital leases. This notion is supported by the previous literature, which finds that firms with higher debt-equity ratio are likely to choose operating leases to lower the ratio (McGregor 1996; Lee 1999; Chung 2000; Yoon and Hong 2001). According to Abdel-Khalik (1981), financial analysts and loan-givers tend to provide a more favorable opinion on companies that adopt operating leases instead of capital leases, even though the two lease types provide similar economic benefits. Hence, companies may attempt to boost their credit ratings and reduce the cost of debt by adopting operating leases for the off-balance-sheet effect, which leads to the first two hypotheses of this study as follows.

Hypothesis 1. Companies that recognize operating leases have higher credit ratings than those that recognize capital leases.

Hypothesis 2. Companies that recognize operating leases have a lower cost of debt than those recognizing capital leases.

Listed and unlisted companies face different market conditions, creating gaps in the quality of the financial reports. While listed firms can raise money from general investors in an open market using either stocks or bonds, unlisted firms depend on private loans from banks or other private parties. Due to these differences in financing conditions, listed and unlisted companies have distinct financial and ownership structures (Cloyd et al. 1996; Ball and Shivakumar 2005; Burghstahler et al. 2006; Hope et al. 2013). The difference also causes a difference in the need to comply with regulations: listed firms must follow strict regulations since they trade on the public market, while unlisted firms do not. Different financial and ownership structure as well as different reporting environments could result in different quality of the financial reports; higher quality of financial information by listed firms versus 
lower quality of financial information by unlisted firms. The different quality of financial reports between listed and unlisted firms opens two possibilities: (1) credit rating agencies and creditors could reflect the difference of listing status during their evaluation and give consistent ratings and cost of debt, or (2) they fail to account for this difference and give different ratings and cost of debt. Either way, the effect of lease selection would be influenced by the listing status. Thus, we propose Hypotheses 3 and 4 as follows:

Hypothesis 3. The effect of lease selection on credit ratings differs based on the listing status.

Hypothesis 4. The effect of lease selection on the cost of debt differs based on the listing status.

\section{Data and Sample}

\subsection{Sample Selection}

We collect sample data for 2000 to 2014 from the KIS VALUE database. However, our research design requires one-year lag data and one-year lead data, resulting in a final sample period of 13 years, from 2001 to 2013. We select the final sample using several filtering rules. We include (1) only companies with fiscal years ending in December for the sake of homogeneity; and exclude (2) enterprises with an auditor's opinion other than 'unqualified' to remove unreliable samples, (3) firms with impaired capital because their financial statements could be less reliable than those of ordinary firms and (4) companies that do not recognize leases at all or those that recognize both capital and operating leases to enable an analysis of the result of adopting different lease accounting methods. In total, 6133 observations satisfy all filter rules. Finally, to deal with outliers, all variables except the dummy variables and natural-logarithm-transformed variables are winsorized at the top and bottom $1 \%$ level. Panel A of Table 1 illustrates the sample selection process.

According to the frequency analysis of each lease type in Panel B of Table 1, 3486 firms (56.84\%) in the sample prefer to recognize operating leases on their financial statements, while 2647 (43.16\%) opt for capital leases. This indicates that operating leases are more widely adopted than capital leases are.

Panel C of Table 1 describes the distribution of the sample by industry based on the high-level classification standards of KIS VALUE. Of the sample, 3215 firms (52.42\%) belong to the manufacturing sector, followed by 1073 (17.50\%) in other industrial sectors, 794 (12.95\%) in the service sector, $686(11.19 \%)$ in the wholesale or retail sector and $365(5.95 \%)$ in the construction sector.

Table 1. Sample distribution.

Panel A: Sample selection process.

\begin{tabular}{lc}
\hline Initial sample firms operating in financial industry between 2001and $2013^{1}$ & 332,878 \\
Less: firms whose fiscal year-end fall in the month other than December & $(16,436)$ \\
Less: firms which receive an audit opinion other than an unqualified one & $(165,556)$ \\
Less: firms which record impaired capital & $(9975)$ \\
Less: firms which explicitly choose one methods for lease transactions between operating and capital & $(134,778)$ \\
lease 2 as well as have no missing calculating values for model variables in Equations $(1)$ and $(2)$ & 6133 \\
Final sample
\end{tabular}

Note $^{1}$ : Since firms must have one-year lag data to calculate model variables in the analysis, the initial sample period includes observations from 2000. Note ${ }^{2}$ : To make a more effective comparison, we exclude firms that record both lease accounting methods from the sample.

Panel B: Composition of the sample (2001-2013).

\begin{tabular}{cc}
\hline Lease Accounting & Total \\
\hline Operating Lease & $3486(56.84 \%)$ \\
Capital Lease & $2647(43.16 \%)$ \\
Total & $6133(100.00 \%)$
\end{tabular}

Note: Since the analyses require lag data, the baseline data range is from 2000 to 2013. 
Panel C: Industrial distribution of the sample (2000-2013).

\begin{tabular}{cccc}
\hline Industry & Listed Firms & Unlisted Firms & Total \\
\hline Manufacturing & $659(56.66 \%)$ & $2556(51.43 \%)$ & $3215(52.42 \%)$ \\
Wholesale \& Retail & $72(6.19 \%)$ & $614(12.35 \%)$ & $686(11.19 \%)$ \\
Construction & $37(3.18 \%)$ & $328(6.60 \%)$ & $365(5.95 \%)$ \\
Service & $237(20.38 \%)$ & $557(11.21 \%)$ & $794(12.95 \%)$ \\
Other & $158(13.59 \%)$ & $915(18.41 \%)$ & $1073(17.50 \%)$ \\
Total & $1163(100.00 \%)$ & $4970(100.00 \%)$ & $6133(100.00 \%)$ \\
\hline
\end{tabular}

Note: Since firms must have one-year lag data to calculate model variables in the analysis, the initial sample period includes observations from 2000.

\subsection{Research Design}

Our hypotheses have been developed under the assumption that the lease selection drives credit ratings or cost of debt. However, it is also possible that credit ratings and cost of debt act as constraints on the firm's lease selection: a firm may choose to use operating lease because they have low credit ratings or high cost of debt in a desperate attempt to alleviate its position. Such relations introduce potential endogenous concerns. Although the equations do consider lagged variables, it may not fully address this issue since credit ratings, cost of debt and lease selection are all likely to persist over long periods of time. Consequently, as an additional method to address endogenous concern, we adopt the Heckman two-stage model (Chaney et al. 2004; Heckman 1979).

\subsubsection{First Stage Model}

In the first stage, we construct the probit regression model, Equation (1) based on the previous studies (Park and Na 2017). The dependent variable, $D L$, is equal to one if a firm selects an operating lease and zero if a firm select capital lease. The explanatory variables in Equation (1) are factors that could affect lease selection based on previous studies: Leverage ( $L E V)$, effective tax rate (TAXRATE), free cash flow $(F C F)$, return on assets $(R O A)$, capital intensity $(C I)$, size (SIZE) and industry and year dummies. In the first stage, we calculate the Inverse Mills Ratio (IMR), which is included in the second stage model as a control variable.

Variables TAXRATE and CI are included in Equation (1) but not in subsequent Equation (2) or Equation (3) because they are known to affect lease selection but neither credit ratings nor cost of debts based on the previous studies. Although the total cost stays equal regardless of the lease type selected (Imhoff et al. 1991; Shawn and Lee 2015), recording capital lease results in higher costs compared to operating lease in the early period and lower costs in the later period. Thus, tax payment can be deferred in the case of capital lease. Due to this deferment, firms may choose capital lease to decrease tax payment in the early period of the lease when the effective tax rate is high (Holthausen and Leftwich 1983; El-Gazzar et al. 1986; Lee 1999). However, the effective tax rate is not related to credit ratings or cost of debts.

Also, capital intensity of a firm is associated with lease selection in terms of the degree of complexity of lease accounting. Capital lease requires a firm to calculate principal repayments and interest expense using effective interest rate as well as depreciation. On the other hand, a firm simply records lease payment as an expense when lease fee is paid, making operating lease is far simpler than capital lease to record. Since firms with higher capital intensity are usually larger and thus able to handle complex accounting treatment, those firms are likely to choose capital lease (Lee 1999). As discussed above, capital intensity is related to the degree of complexity of accounting treatment but not related to credit ratings or cost of debts.

$$
\begin{aligned}
D L_{t}=\alpha_{0}+\alpha_{1} L E V_{t} & +\alpha_{2} \text { TAXRATE }_{t-1}+\alpha_{3} S_{I Z E_{t}+\alpha_{4} F C F_{t}} \\
& +\alpha_{5} \text { ROA }_{t}+\alpha_{6} C I_{t}+\sum I N D+\sum Y D+\varepsilon
\end{aligned}
$$


where $D L_{t}=$ dummy variable which equals 1 for a firm's choice of an operating lease and 0 for a firm's choice of a capital lease; $L E V_{t}=$ Leverage (= total liability/total asset); TAXRATE $E_{-1}=$ Effective income tax rate (= income tax/net income before taxes); $S I Z E_{t}=$ Firm size (natural logarithm of total asset); $F C F_{t}=$ Free cash flow $[=(($ cash flow from operations $)-($ cash flow from investing activities $)) /$ total asset]; $R O A_{t}$ : Return on assets (= net income/total assets); $C I_{\mathrm{t}}=$ Total assets per capital (natural logarithm of intangible assets divided by the number of employees); $\Sigma I N D=$ industry dummy; $\Sigma Y D=$ year dummy; and $\varepsilon=$ error term.

\subsubsection{Second Stage Model (Main Research Design)}

To test the first hypothesis whether firms recognizing operating leases receive higher credit ratings than those recognizing capital leases, we construct the following ordered probit regression model (Equation (2)):

$$
\begin{aligned}
\text { RATING }_{t+1}= & \beta_{0}+\beta_{1} D L_{t}+\beta_{2} \text { BIG }_{t}+\beta_{3} \text { SIZE }_{t}+\beta_{4} L E V_{t}+\beta_{5} L I Q_{t}+\beta_{6} G R W_{t} \\
& +\beta_{7} \text { ROA }_{t}+\beta_{8} L_{\text {LSS }}+\beta_{9} \Delta C F O_{t}+\beta_{10} L n A G E_{t}+\beta_{11} \text { GROUP }_{t} \\
& +\beta_{12} I M R_{t}+\sum I N D+\sum Y D+\varepsilon
\end{aligned}
$$

where $\operatorname{RATING}_{t+1}=$ the firm's credit rating in year $t+1 ; D L_{t}=$ a dummy variable equal to 1 for a firm recording an operating lease and 0 for those recording a capital lease; $B I G 4_{t}=$ a dummy variable equal to 1 if a firm's auditor is a Big-4 auditing firm and 0 otherwise; $S I Z E_{t}=$ firm size (natural logarithm of total assets) in year $t ; L E V_{t}=$ leverage (total liabilities/total assets) in year $t ; L I Q_{t}=$ liquidity ratio (current assets/current liabilities) in year $t ; G R W_{t}=$ growth rate [(sales in year $t$ less sales in year $t-1$ )/total assets in $t-1$ ] in year $t, R O A_{t}=$ return on assets (net income/total assets) in year $t ; L_{L S S}$ = a dummy variable equal to 1 if a firm reports a loss in year $t$ and 0 otherwise; $\triangle C F O_{t}=$ changes in

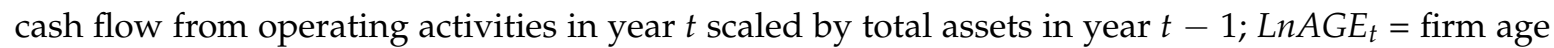
(natural logarithm of number of years from inception) in year $t ; G R O U P_{t}=$ a dummy variable equal to 1 if a firm is an affiliate of a corporate group and 0 otherwise; $I M R_{t}=$ Inverse Mills Ratio calculated from the first stage; $\Sigma I N D=$ industry dummy; $\Sigma Y D=$ year dummy; and $\varepsilon=$ error term.

Since the dependent variable in Equation (2) is credit rating, an ordinal variable, we assume that the ordered probit regression model is suitable for this study. To control for clustering effects, we use robust standard errors when calculating the Wald $X^{2}$ statistics. Specifically, we measure credit ratings (RATING) in the following year $(t+1)$ using data provided by KIS VALUE. Following previous studies, we rate companies with the highest credit rating at 10 points and those with the lowest rating at 1 point (Park et al. 2012; Park and Yoon 2013). The variable of interest (i.e., the test variable) is the dummy variable for lease selection $(D L)$. As firms with larger debt-equity ratios tend to have lower credit ratings (Jeon and Lee 2015), companies are likely to prefer operating leases to capital leases not to increase the debt-equity ratio (Lee 1999; Chung 2000; Yoon and Hong 2001). Therefore, based on the assumption discussed above, we expect that $D L$ will significantly and positively affect RATING.

We develop the control variables for this study based on variables identified as determinants of credit ratings in previous studies on corporate credit ratings. They are BIG4(audit quality), SIZE(firm-size), LEV(leverage), LIQ(liquidity ratio), GRW(sales growth), ROA(return on asset), LOSS(loss in the current period), $\triangle C F O$ (change in cash flows from operations), LnAGE(firm-age) and GROUP(affiliation with a business group). Prior studies (Teoh and Wong 1993; Becker et al. 1998; Krishnan 2003) show that companies audited by an auditor from one of the Big-4 auditing firms tend to produce better quality audits and find a positive relationship between BIG4 and RATING (Park and Nam 2014). Therefore, we expect to see significantly positive values with BIG4. Following previous studies that have found that larger companies can enjoy greater stability as a going concern and thus receive better credit ratings (Kim 2006; Park and Yoon 2013), we include the control variable SIZE as the natural logarithm of total assets as a proxy for firm size. We also use SIZE as a proxy of variables that we omit in the model (Becker et al. 1998). Considering the results of prior research, we predict 
that SIZE will influence RATING in a positive direction. LEV represents long-term financial stability. Previous research demonstrates that the higher a company's debt-equity ratio, the lower the credit ratings it receives (Park and Nam 2010; Park and Yoon 2013). Hence, we expect a negative relationship between $L E V$ and RATING.

$L I Q$ represents short-term financial stability. Broadly, firms with a lower liquidity ratio have lower credit ratings (Kim 2006; Park and Nam 2010). We thus expect to discover a positive relationship between LIQ and RATING. Park and Yoon (2013) argue that, while companies that record greater sales growth may receive positive assessments from credit rating agencies, they may also get negative opinions because there are more incentives for earnings management. Thus, Park and Yoon (2013) find it difficult to predict the relationship between GRW and RATING and do not set a direction. For the same reason, we do not establish a specific direction regarding GRW.

$R O A$ represents corporate profitability and higher profitability will result in higher credit ratings. Lee (2011) insists that companies with higher return on assets tend to obtain higher ratings for corporate bonds. In this regard, we expect a positive relationship between ROA and RATING. LOSS, which is 1 when a company has negative net income and 0 otherwise, represents firms that report loss. Because reporting a loss may cause lower credit ratings (Park and Nam 2010; Park and Yoon 2013), we expect a negative relationship between LOSS and RATING. We calculate $\triangle C F O$ by deducting operating cash flows in the previous term from operating cash flows in the current term and dividing the outcome by total beginning assets. Based on a previous research (Park and Yoon 2013) finding that more of active operating cash flows lead to higher credit ratings, we expect that $\triangle C F O$ and RATING will show a positive relationship.

For LnAGE, Park and Yoon (2013) suggest that older companies are more stable and receive higher credit ratings as a result. Reflecting these findings, we also expect that $L n A G E$ will relate positively with RATING. A company within a corporate group may engage in insider trading with its affiliated businesses, which can exacerbate information asymmetry (Park and Yoon 2013). As credit rating agencies may perceive it as a negative element, we predict that GROUP and RATING will have a negative relationship. Finally, we include year and industry dummy variables in Equation (2) to control for year and industry effects.

The second model we employ is the ordinary least square (OLS) regression model designed to investigate whether companies recognizing operating leases can lower their cost of debt compared to firms recognizing capital leases. Like Equation (2), we use robust standard errors for calculating t-values to control for clustering effects.

$$
\begin{aligned}
& C O D_{t+1}=\beta_{0}+\beta_{1} D L_{t}+\beta_{2} B I G 4_{t}+\beta_{3} S I Z E_{t}+\beta_{4} L E V_{t}+\beta_{5} L I Q_{t}+\beta_{6} G R W_{t}+\beta_{7} R O A_{t} \\
& +\beta_{8} \text { LOSS }_{t}+\beta_{9} \Delta C F O_{t}+\beta_{10} \operatorname{LnAGE}_{t}+\beta_{11} \text { GROUP }_{t}+\beta_{12} \text { RATING }_{D D t+1} \\
& +\beta_{13} I M R_{t}+\sum I N D+\sum Y D+\varepsilon
\end{aligned}
$$

where $C O D_{t+1}=$ borrowing interest rates, defined as total finance costs divided by average interest on debt in year $\mathrm{t}_{\mathrm{t}+1}$; and $R A T I N \mathrm{~A}_{-} D D_{t+1}=$ residuals of $\log [($ corporate credit ratings +1$)]$ in year $t+1$ based on Equation (4).

The dependent variable in Equation (3) is the cost of debt proxied by the debt borrowing rate (COD) (Kwak and Park 2011; Park and Yoon 2013). We calculate COD by dividing total interest expenses by average interest-bearing liabilities in year $_{t+1}$. Equation (3) has the same test variable as in Equation (2). Companies favor operating leases over capital leases because they do not increase debt and provide an off-balance-sheet effect and helps them borrow funds at lower interest rates later. Based on Hypothesis 2, we assume that firms adopting operating leases can borrow debt at lower costs in the following year and thus we expect $D L$ and $C O D$ will have a negative relationship.

We establish the control variables in Equation (3) based on previous research related to the cost of debt. Except for RATING_DD $D_{t+1}$, all other control variables are the same as those in Equation (2) but we may expect different relationships with COD. Several previous studies find that firms audited by one of the Big-4 accounting firms (BIG4) have a lower cost of debt (Karjalainen 2011; 
Kwak and Park 2011). Therefore, we presume that BIG4 and COD have a negative relationship. Since larger companies tend to have a lower cost of debt (Kim 2006; Park and Yoon 2013), we expect a negative relationship between SIZE and COD.

As a higher debt-equity ratio lowers a firm's ability to repay debt in the future, companies with higher debt-equity ratio pay more for debt financing (Park and Yoon 2013); thus, we expect a positive relationship between $L E V$ and $C O D$. For $L I Q$, prior research provides mixed results (Park and Yoon 2013). While some studies discovered a significantly positive relationship between liquidity ratio and cost of debt for companies listed on the Korea Stock Exchange, others do not find any significant relationship for those listed on the Korea Securities Dealers Automated Quotation (KOSDAQ); thus, we do not set a specific direction between LIQ and COD. While the variable GRW contains information about companies' future growth potential, those with higher growth potential are more likely to engage in earnings management activities, thereby having a better chance of creating financial distortions. Since companies with greater sales growth may have a higher cost of debt (Park and Yoon 2013), we expect that GRW and COD will be positively related.

Companies that record a higher ROA are less vulnerable to default (Francis et al. 2005), so those with higher debt repayment capabilities and lower risk of bankruptcy can borrow funds at lower interest rates (Kwak and Park 2011). Hence, we expect a negative correlation between ROA and COD.

Since reporting a loss tends to raise the cost of debt (Park and Yoon 2013), we expect a positive relationship between LOSS and COD. Previous studies find that fewer changes in operating cash flows are linked to a higher cost of debt (Park and Yoon 2013). In this respect, we expect a negative relationship between $\triangle C F O$ and $C O D$. Previous research does not clearly verify the relationship between LnAGE and cost of debt(Park and Yoon 2013): for firms listed on the Korea Stock Exchange, those with longer LnAGE have a higher cost of debt, while firms listed on the KOSDAQ do not show any significant relationship (Park and Yoon 2013). Therefore, we do not set a specific direction for LnAGE. Bond investors view companies belonging to a corporate group as carrying more risk in that they are more likely to engage in earnings management activities (Park and Yoon 2013). In this sense, we expect a positive relationship between GROUP and COD.

Finally, RATING_DD $D_{t+1}$ refers to the residuals (orthogonalized RATING) estimated through regression analysis (OLS) based on Equation (4), which uses the natural logarithm of RATING (credit ratings) plus 1 as a dependent variable ${ }^{2}$, with the other variables of Equation (2) as explanatory variables.

$$
\begin{aligned}
\operatorname{LogRATING}_{t+1} & =\beta_{0}+\beta_{1} D L_{t}+\beta_{2} \text { BIG }_{t}+\beta_{3} \operatorname{SIZE}_{t}+\beta_{4} L E V_{t}+\beta_{5} L I Q_{t}+\beta_{6} G R W_{t} \\
& +\beta_{7} R O A_{t}+\beta_{8} L_{\text {LSS }}+\beta_{9} \Delta C F O_{t}+\beta_{10} L n A G E_{t}+\beta_{11} \text { GROUP }_{t} \\
& +\sum I N D+\sum Y D+\varepsilon
\end{aligned}
$$

where $\log R A T I N G_{t+1}=$ natural logarithm of $R A T I N G$ in year $t+1$ plus 1 .

Further, RATING_DD $D_{t+1}$ is not correlated with the explanatory variables other than RATING, so it alleviates the issue of multicollinearity while maintaining the effect of RATING on the dependent variable. As such, we use it as a control variable for Hypothesis 2. Previous studies report that companies with higher credit ratings spend less (Park 2011) and we expect a negative relationship between RATING_DD $D_{t+1}$ and $C O D$.

\section{Results}

\subsection{Descriptive Statistics}

Table 2 presents the descriptive statistics of the key variables. The mean (median) of RATING is 5.026 (5.000), while that of COD is $0.061(0.056)$, suggesting that on average, the sample firms have a credit rating of about 5 and pay interest of about $6.1 \%$. The mean (median) value of $D L$ is

2 We use natural logarithm of credit ratings as a dependent variable following Ge and Kim (2013). 
0.568 (1.000), meaning that $56.8 \%$ of the sample firms recognize operating leases in their financial statements. Meanwhile, considering that the mean (median) of BIG4 is $0.271(0.000)$, the sample firms are more likely to be audited by non-BIG-4 accounting firms. The mean (median) of SIZE is 24.578 (24.150). The mean (median) of LEV and LIQ are 0.619 (0.647) and 1.263 (0.987), respectively, which indicate that the sample firms have less debt than assets and lower current liabilities than current assets. The mean (median) value of GRW is 0.127 (0.063) while that of ROA is $0.038(0.031)$. In terms of LOSS, the mean (median) stands at 0.180 (0.000), which proves that more firms in the sample record net profits. Furthermore, the mean (median) $\triangle C F O$ of $0.006(0.004)$ shows that these firms on average have relatively high cash flow from operations. The mean (median) value of LnAGE is 2.749 (2.773), while that of GROUP is 0.475 (0.000), which suggests that about $47.5 \%$ of the sample firms belong to a corporate group.

Table 2. Descriptive statistics (sample period $=2001-2013$ ).

\begin{tabular}{ccccccccc}
\hline Variable & Mean & Std. Deb & Min & $\mathbf{2 5 \%}$ & Median & $\mathbf{7 5 \%}$ & Max & N \\
\hline RATING & 5.026 & 1.728 & 1.000 & 4.000 & 5.000 & 6.000 & 10.000 & 6133 \\
COD & 0.061 & 0.034 & 0.003 & 0.043 & 0.056 & 0.070 & 0.262 & 6133 \\
DL & 0.568 & 0.495 & 0.000 & 0.000 & 1.000 & 1.000 & 1.000 & 6133 \\
BIG4 & 0.271 & 0.444 & 0.000 & 0.000 & 0.000 & 1.000 & 1.000 & 6133 \\
SIZE & 24.578 & 1.414 & 22.857 & 23.586 & 24.150 & 25.130 & 29.695 & 6133 \\
LEV & 0.619 & 0.196 & 0.123 & 0.488 & 0.647 & 0.767 & 0.970 & 6133 \\
LIQ & 1.263 & 1.161 & 0.034 & 0.642 & 0.987 & 1.450 & 7.968 & 6133 \\
GRW & 0.127 & 0.392 & -1.025 & -0.030 & 0.063 & 0.226 & 1.949 & 6133 \\
ROA & 0.038 & 0.083 & -0.249 & 0.006 & 0.031 & 0.073 & 0.324 & 6133 \\
LOSS & 0.180 & 0.384 & 0.000 & 0.000 & 0.000 & 0.000 & 1.000 & 6133 \\
$\triangle$ CFO & 0.006 & 0.141 & -0.443 & -0.059 & 0.004 & 0.070 & 0.495 & 6133 \\
LnAGE & 2.749 & 0.656 & 1.099 & 2.303 & 2.773 & 3.219 & 4.060 & 6133 \\
GROUP & 0.475 & 0.499 & 0.000 & 0.000 & 0.000 & 1.000 & 1.000 & 6133 \\
\hline NRT
\end{tabular}

Notes: Variables definitions are as follows: RATING $_{t+1}=$ firm's credit rating in year $t+1 ; C O D_{t+1}=$ borrowing interest rates, defined as total finance costs divided by average interests accruing to the debt in year $t+1 ; D L_{t}=\mathrm{a}$ dummy variable which equals 1 for a firm recording operating lease and 0 otherwise; $B I G 4_{t}=$ a dummy variable which equals 1 if a firm's auditor comes from a big accounting firm (namely Big 4 audit firms) and 0 otherwise; $S I Z E_{t}=$ firm size (natural logarithm of total asset) in year $t ; L E V_{t}=$ leverage (total liability/total asset) in year $t ; L I Q_{t}$ $=$ liquidity ratio (current asset/current liability) in year $t ; G R W_{t}=$ growth rate [(sales in $t$ less sales in $\left.t-1\right) /$ total asset in $t-1] ; R O A_{t}=$ return on assets(net income/total assets) in year $t ; L O S S_{t}=$ a dummy variable which equals 1 for a firm reporting loss in year $t$ and 0 otherwise; $\Delta C F O_{t}=$ changes in cash flow from operating activities in $t$ scaled by total asset in $t-1 ; L n A G E_{\mathrm{t}}=$ firm age (natural logarithm of number of years from the inception) in year $t$ ); $G R O U P_{t}=$ a dummy variable which equals 1 if a firm is an affiliation of a corporate group and 0 otherwise.

\subsection{Correlation Analysis}

Table 3 describes the Pearson correlations between key variables. It first presents the correlation between the variables of Equation (2) to test Hypothesis 1. The coefficient between RATING and DL is 0.049 and is significantly positive at the $1 \%$ level. This shows that adopting an operating lease may lead to higher credit ratings. As for the control variables, the coefficient of BIG4 is 0.041 and is significant at the $1 \%$ level. The coefficients of LIQ, GRW, ROA, $\triangle$ CFO, LnAGE and GROUP are 0.362, 0.062, 0.478, $0.129,0.044$ and 0.041 , respectively, which are all significant at the $1 \%$ level. In contrast, the coefficient of the control variable SIZE is -0.023 and significant at the $10 \%$ level. In addition, the coefficients of $L E V$ and LOSS are -0.603 and -0.344 , respectively, presenting a negative correlation that is significant at the $1 \%$ level.

Next, we examine the correlations between the variables of Equation (3) to test Hypothesis 2. The correlation coefficient between $C O D$ and $D L$ is -0.137 , which is significant at the $1 \%$ level. As for the correlations of $C O D$ with the control variables, its correlation coefficients with BIG4, SIZE, LEV, LIQ, GRW, LOSS and GROUP are 0.072, 0.047, 0.039, 0.034, 0.058, 0.085 and 0.088, respectively, all significant at the $1 \%$ level. The correlation between COD and ROA is -0.099 and significant at the $1 \%$ level, while that with $\operatorname{LnAGE}$ is -0.029 and significant the $5 \%$ level. 
Table 3. Correlation matrix.

\begin{tabular}{|c|c|c|c|c|c|c|c|c|c|c|c|c|c|}
\hline Variable & RATING & $C O D$ & $D L$ & BIG4 & SIZE & $L E V$ & $L I Q$ & GRW & $R O A$ & LOSS & $\triangle C F O$ & LnAGE & GROUP \\
\hline RATING & 1.000 & & & & & & & & & & & & \\
\hline$C O D$ & $\begin{array}{l}-0.077 \\
(0.000)\end{array}$ & 1.000 & & & & & & & & & & & \\
\hline$D L$ & $\begin{array}{c}0.049 \\
(0.000) \\
\end{array}$ & $\begin{array}{l}-0.137 \\
(0.000) \\
\end{array}$ & 1.000 & & & & & & & & & & \\
\hline BIG4 & $\begin{array}{c}0.041 \\
(0.001)\end{array}$ & $\begin{array}{c}0.072 \\
(0.000)\end{array}$ & $\begin{array}{r}-0.329 \\
(0.000)\end{array}$ & 1.000 & & & & & & & & & \\
\hline SIZE & $\begin{array}{l}-0.023 \\
(0.071) \\
\end{array}$ & $\begin{array}{c}0.047 \\
(0.000) \\
\end{array}$ & $\begin{array}{l}-0.445 \\
(0.000) \\
\end{array}$ & $\begin{array}{c}0.489 \\
(0.000) \\
\end{array}$ & 1.000 & & & & & & & & \\
\hline$L E V$ & $\begin{array}{l}-0.603 \\
(0.000) \\
\end{array}$ & $\begin{array}{c}0.039 \\
(0.002) \\
\end{array}$ & $\begin{array}{l}-0.103 \\
(0.000) \\
\end{array}$ & $\begin{array}{l}-0.057 \\
(0.000) \\
\end{array}$ & $\begin{array}{c}0.013 \\
(0.316) \\
\end{array}$ & 1.000 & & & & & & & \\
\hline LIQ & $\begin{array}{c}0.362 \\
(0.000) \\
\end{array}$ & $\begin{array}{c}0.034 \\
(0.007) \\
\end{array}$ & $\begin{array}{c}0.100 \\
(0.000) \\
\end{array}$ & $\begin{array}{l}-0.018 \\
(0.156) \\
\end{array}$ & $\begin{array}{l}-0.105 \\
(0.000) \\
\end{array}$ & $\begin{array}{l}-0.556 \\
(0.000) \\
\end{array}$ & 1.000 & & & & & & \\
\hline GRW & $\begin{array}{c}0.062 \\
(0.000)\end{array}$ & $\begin{array}{c}0.058 \\
(0.000)\end{array}$ & $\begin{array}{l}-0.033 \\
(0.009)\end{array}$ & $\begin{array}{c}0.016 \\
(0.198)\end{array}$ & $\begin{array}{l}-0.014 \\
(0.274)\end{array}$ & $\begin{array}{c}0.086 \\
(0.000)\end{array}$ & $\begin{array}{l}-0.036 \\
(0.005)\end{array}$ & 1.000 & & & & & \\
\hline$R O A$ & $\begin{array}{c}0.478 \\
(0.000) \\
\end{array}$ & $\begin{array}{l}-0.099 \\
(0.000) \\
\end{array}$ & $\begin{array}{c}0.044 \\
(0.001) \\
\end{array}$ & $\begin{array}{l}-0.023 \\
(0.075) \\
\end{array}$ & $\begin{array}{l}-0.048 \\
(0.000) \\
\end{array}$ & $\begin{array}{l}-0.275 \\
(0.000) \\
\end{array}$ & $\begin{array}{c}0.180 \\
(0.000)\end{array}$ & $\begin{array}{c}0.310 \\
(0.000)\end{array}$ & 1.000 & & & & \\
\hline LOSS & $\begin{array}{l}-0.344 \\
(0.000)\end{array}$ & $\begin{array}{c}0.085 \\
(0.000)\end{array}$ & $\begin{array}{l}-0.045 \\
(0.000)\end{array}$ & $\begin{array}{c}0.084 \\
(0.000)\end{array}$ & $\begin{array}{c}0.069 \\
(0.000)\end{array}$ & $\begin{array}{c}0.128 \\
(0.000)\end{array}$ & $\begin{array}{l}-0.050 \\
(0.000)\end{array}$ & $\begin{array}{l}-0.159 \\
(0.000)\end{array}$ & $\begin{array}{l}-0.630 \\
(0.000)\end{array}$ & 1.000 & & & \\
\hline$\triangle C F O$ & $\begin{array}{c}0.129 \\
(0.000) \\
\end{array}$ & $\begin{array}{l}-0.014 \\
(0.257) \\
\end{array}$ & $\begin{array}{l}-0.038 \\
(0.003) \\
\end{array}$ & $\begin{array}{c}0.015 \\
(0.241) \\
\end{array}$ & $\begin{array}{c}0.003 \\
(0.801) \\
\end{array}$ & $\begin{array}{c}0.012 \\
(0.329) \\
\end{array}$ & $\begin{array}{l}-0.035 \\
(0.006) \\
\end{array}$ & $\begin{array}{c}0.183 \\
(0.000) \\
\end{array}$ & $\begin{array}{c}0.141 \\
(0.000) \\
\end{array}$ & $\begin{array}{l}-0.083 \\
(0.000)\end{array}$ & 1.000 & & \\
\hline $\operatorname{LnAGE}$ & $\begin{array}{c}0.044 \\
(0.001)\end{array}$ & $\begin{array}{l}-0.029 \\
(0.023)\end{array}$ & $\begin{array}{l}-0.078 \\
(0.000)\end{array}$ & $\begin{array}{c}0.082 \\
(0.000)\end{array}$ & $\begin{array}{c}0.265 \\
(0.000)\end{array}$ & $\begin{array}{l}-0.147 \\
(0.000)\end{array}$ & $\begin{array}{c}0.000 \\
(0.981)\end{array}$ & $\begin{array}{l}-0.137 \\
(0.000)\end{array}$ & $\begin{array}{l}-0.062 \\
(0.000)\end{array}$ & $\begin{array}{c}0.012 \\
(0.362)\end{array}$ & $\begin{array}{l}-0.028 \\
(0.029)\end{array}$ & 1.000 & \\
\hline GROUP & $\begin{array}{c}0.041 \\
(0.001)\end{array}$ & $\begin{array}{c}0.088 \\
(0.000)\end{array}$ & $\begin{array}{c}-0.313 \\
(0.000)\end{array}$ & $\begin{array}{c}0.325 \\
(0.000)\end{array}$ & $\begin{array}{c}0.431 \\
(0.000)\end{array}$ & $\begin{array}{l}-0.071 \\
(0.000)\end{array}$ & $\begin{array}{c}-0.036 \\
(0.005)\end{array}$ & $\begin{array}{l}-0.001 \\
(0.958)\end{array}$ & $\begin{array}{l}-0.045 \\
(0.000)\end{array}$ & $\begin{array}{c}0.071 \\
(0.000)\end{array}$ & $\begin{array}{c}0.006 \\
(0.628)\end{array}$ & $\begin{array}{c}0.152 \\
(0.000)\end{array}$ & 1.000 \\
\hline
\end{tabular}

Notes: Table 3 reports the Pearson correlation between main variables. Please refer to Table 2 for variable definitions. 


\subsection{Results of Regression Analysis}

\subsubsection{Results of the First Stage Probit Regression}

The results of first stage probit regression are reported in Table 4 . The Wald $X^{2}$ statistic is 1769.76, significant at the $1 \%$ level, while Pseudo $R^{2}$, which represents the explanatory power of the model, is $55.4 \%$. Except for variable $C I$, all other explanatory variables are significant at the conventional level in the same directions as those in the previous studies (see Park and Na 2017). Specifically, variable LEV (Coefficient: -0.8955), SIZE (Coefficient: -0.5615) and FCF (Coefficient: -0.3640) have significant and positive coefficients while variable TAXRATE (Coefficient: 0.2528) and ROA (Coefficient: 0.5691) are significantly and positively related to operating lease selection.

Table 4. 1st Stage Probit Regression Results

\begin{tabular}{|c|c|c|c|}
\hline \multicolumn{4}{|c|}{ 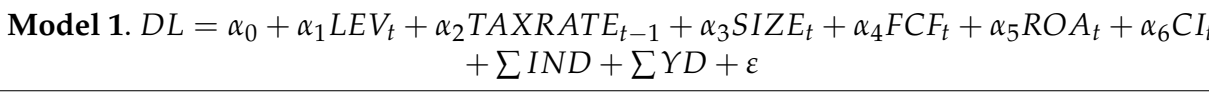 } \\
\hline \multirow[b]{2}{*}{ Variable } & \multirow[b]{2}{*}{ Pred. Sign } & \multicolumn{2}{|c|}{ Dependent Variable: $D L$} \\
\hline & & Coefficient & Wald $X^{2}$-Value \\
\hline Intercept & $+/-$ & 14.0328 & 2.11 \\
\hline$L E V$ & + & -0.8955 & $62.91^{* * *}$ \\
\hline TAXRATE & + & 0.2528 & $8.61^{* * *}$ \\
\hline SIZE & - & -0.5615 & $719.90^{* * *}$ \\
\hline FCF & - & -0.3640 & $6.96^{* *}$ \\
\hline$R O A$ & + & 0.5691 & $4.80^{* *}$ \\
\hline$C I$ & - & 0.0023 & 0.56 \\
\hline$\Sigma I N D$ & & \multirow{2}{*}{\multicolumn{2}{|c|}{$\begin{array}{l}\text { Included } \\
\text { Included }\end{array}$}} \\
\hline$\Sigma Y D$ & & & \\
\hline Wald $X^{2}$ & & \multicolumn{2}{|c|}{$1769.76^{* * *}$} \\
\hline Pseudo $R^{2}$ & & \multicolumn{2}{|c|}{$55.4 \%$} \\
\hline $\mathrm{N}$ & & \multicolumn{2}{|c|}{6133} \\
\hline
\end{tabular}

Notes: Explanatory power and fitness of the probit regression model are expressed by Pseudo $R^{2}$ and Wald $X^{2}$. $* * *, * *$ and ${ }^{*}$ denote significance at $1 \%, 5 \%, 10 \%$ levels, respectively (two-tailed). Please refer to Table 2 for variable definitions.

\subsubsection{Main Results: Ordered Probit Regression Results for H1}

Table 5 presents the ordered probit regression (cluster-adjusted) results of the effect of recognizing operating leases on corporate credit ratings related to Hypothesis 1 . The Wald $X^{2}$ statistic is 2352.73, significant at the $1 \%$ level, while Pseudo $R^{2}$, which represents the explanatory power of the model, is $51.70 \%{ }^{3}$

The coefficient estimate of the test variable $D L$ is 0.1239 but is not statistically significant, showing that lease selection does not have a significant impact on credit ratings. These results correspond to findings in prior research that financial experts at credit rating agencies conduct a thorough scrutiny of each category of financial statements to check for the financial risk underlying the component of liabilities and reflect their observations in credit ratings (Jeon and Lee 2015). The costs incurred during the lease period do not differ in practical terms, regardless of the lease option companies decide to select (Shawn and Lee 2015). Therefore, this study verifies that credit ratings do not reflect lease selection because credit rating agencies consider capital and operating leases to be equivalent. The results for the control variables are in line with those of previous research.

3 Since there are 10 levels of credit rating from 1 to 10, which results in multiple levels of intercepts, we drop the intercepts in Tables 5 and 7 in order to avoid any confusion. 
Table 5. Cluster-adjusted ordered probit regression results for $\mathrm{H} 1$.

\begin{tabular}{|c|c|c|c|}
\hline \multicolumn{4}{|c|}{$\begin{aligned} \text { Model 2. } & \text { RATING }_{t+1}=\beta_{0}+\beta_{1} D L_{t}+\beta_{2} B_{I G 4_{t}}+\beta_{3} \operatorname{SIZE}_{t}+\beta_{4} L E V_{t}+\beta_{5} L I Q_{t}+\beta_{6} G R W_{t}+\beta_{7} R O A_{t} \\
& +\beta_{8} L_{O S S}+\beta_{9} \Delta C F O_{t}+\beta_{10} L n A G E_{t}+\beta_{11} G R O U P_{t}+\beta_{12} I M R_{t}+\sum I N D+\sum Y D+\varepsilon\end{aligned}$} \\
\hline \multirow[b]{2}{*}{ Variable } & \multirow[b]{2}{*}{ Pred. Sign } & \multicolumn{2}{|c|}{ Dependent Variable: RATING } \\
\hline & & Coefficient & Wald $X^{2}$-Value \\
\hline$D L$ & + & 0.1239 & 2.33 \\
\hline BIG4 & + & 0.0903 & 1.35 \\
\hline SIZE & + & -0.1250 & $10.09^{* * *}$ \\
\hline$L E V$ & - & -6.6855 & $963.96^{* * *}$ \\
\hline$L I Q$ & + & 0.1016 & $10.03^{* * *}$ \\
\hline GRW & $+/-$ & -0.0185 & 0.07 \\
\hline$R O A$ & + & 8.1026 & $278.00^{* * *}$ \\
\hline LOSS & - & -0.8384 & $90.69^{* * *}$ \\
\hline$\triangle C F O$ & + & 1.5147 & $84.39 * * *$ \\
\hline $\operatorname{Ln} A G E$ & + & -0.0100 & 0.04 \\
\hline GROUP & - & 0.0372 & 0.25 \\
\hline$I M R$ & $+/-$ & 0.2260 & $11.92^{* * *}$ \\
\hline$\Sigma I N D$ & & \multirow{2}{*}{\multicolumn{2}{|c|}{$\begin{array}{l}\text { Included } \\
\text { Included }\end{array}$}} \\
\hline$\Sigma Y D$ & & & \\
\hline Wald $X^{2}$ & & \multicolumn{2}{|c|}{$2352.73^{* * *}$} \\
\hline Pseudo $R^{2}$ & & \multicolumn{2}{|c|}{$51.70 \%$} \\
\hline $\mathrm{N}$ & & \multicolumn{2}{|c|}{6133} \\
\hline
\end{tabular}

Notes: The explanatory power and fitness of the ordered probit (cluster-adjusted) regression model are expressed by Pseudo $R^{2}$ and Wald $X^{2}$. ${ }^{* * *}$, ** and ${ }^{*}$ denote significance at $1 \%, 5 \%, 10 \%$ levels, respectively (two-tailed). Please refer to Table 2 for variable definitions.

\subsubsection{Main Results: Ordinary Least Square (OLS) Regression Results for H2}

Table 6 presents the OLS regression (cluster-adjusted) results of the effect of operating leases on firms' cost of debt, as Hypothesis 2 suggests. The $F$ value is 20.25 , which is significant at the $1 \%$ level. In addition, the model has an explanatory power $\left(\operatorname{Adj} . R^{2}\right)$ of $12.0 \%$. The coefficient estimate on the test variable $D L$ is -0.0049 and significant at the $1 \%$ level. This result suggests that companies that recognize operating leases have a lower cost of debt than those that recognize capital leases. The result may be due to the fact that firms are more likely to select operating leases over capital leases since a higher debt-equity ratio means a higher cost of debt (Park et al. 2012; Park and Kim 2013; Park and Nam 2013). As previous research reports, this study verifies through empirical analysis that companies eager to finance debt at a lower cost prefer operating leases to capital leases because the latter increases the debt-equity ratio and therefore the costs of debt. The results for the other control variables are similar to those of previous research. ${ }^{4}$

4 When we use borrowing yield spread (borrowing interest rate deducted by the base money rate interest rate of the three-year treasury bond) (Park and Yoon 2013) as the dependent variable instead of the borrowing interest rate (COD), the results of all analyses are qualitatively similar. 
Table 6. Cluster-adjusted ordinary least square (OLS) regression results for H2.

\begin{tabular}{|c|c|c|c|}
\hline \multicolumn{4}{|c|}{ 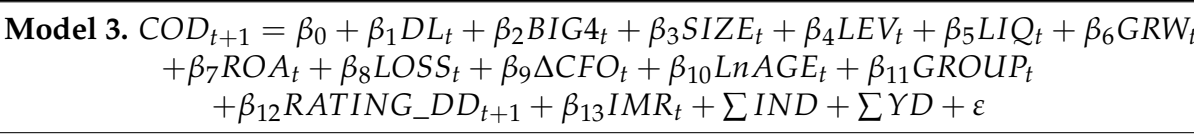 } \\
\hline \multirow[b]{2}{*}{ Variable } & \multirow[b]{2}{*}{ Pred. Sign } & \multicolumn{2}{|c|}{ Dependent Variable: $C O D$} \\
\hline & & Coefficient & $t$-Value \\
\hline Intercept & $+/-$ & 0.0693 & $2.62 * * *$ \\
\hline$D L$ & - & -0.0049 & $-2.87^{* * *}$ \\
\hline BIG4 & - & 0.0009 & 0.55 \\
\hline SIZE & - & -0.0011 & -0.97 \\
\hline$L E V$ & + & 0.0066 & 1.47 \\
\hline$L I Q$ & $+/-$ & 0.0020 & $2.30 * *$ \\
\hline GRW & + & 0.0064 & $3.95 * * *$ \\
\hline$R O A$ & - & -0.0458 & $-4.03^{* * *}$ \\
\hline LOSS & + & 0.0015 & 0.94 \\
\hline$\triangle C F O$ & - & -0.0034 & -1.00 \\
\hline $\operatorname{Ln} A G E$ & $+1-$ & -0.0015 & -1.24 \\
\hline GROUP & + & 0.0015 & 0.77 \\
\hline RATING_DD & - & -0.0047 & $-2.29 * *$ \\
\hline$I M R$ & $+1-$ & 0.0019 & 0.96 \\
\hline$\Sigma I N D$ & & \multicolumn{2}{|c|}{ Included } \\
\hline$\Sigma Y D$ & & \multicolumn{2}{|c|}{ Included } \\
\hline Adj. $R^{2}$ & & \multicolumn{2}{|c|}{$12.0 \%$} \\
\hline F Value & & \multicolumn{2}{|c|}{$20.25 * * *$} \\
\hline $\mathrm{N}$ & & \multicolumn{2}{|c|}{6133} \\
\hline
\end{tabular}

Notes: Explanatory power and fitness of the OLS (cluster-adjusted) regression model are expressed by Adj. $R^{2}$ and $F$-value. ${ }^{* * *},{ }^{* *}$ and ${ }^{*}$ denote significance at $1 \%, 5 \%, 10 \%$ levels, respectively (two-tailed). Please refer to Table 2 for variable definitions.

\subsubsection{Main Results: Ordered Probit Regression Results for H3}

To test Hypothesis 3, we partition the sample into two subsamples, listed firms and unlisted firms and run Equation (2) over the subsamples. Table 7 shows the ordered probit regression (cluster-adjusted) results for the two subsamples. For the listed firms, the coefficient of the test variable $D L$ is 0.0460 but is not statistically significant. For the unlisted firms, the coefficient estimate of $D L$ is 0.1378 , which is again not statistically significant. It seems that the effect of lease selection on credit ratings does not differ significantly according to listing status. This is attributable to the fact that the same financial experts at credit rating agencies closely examine each category of financial statements for both listed and unlisted companies (Jeon and Lee 2015), so the effect of lease selection on credit ratings has the same effect, regardless of listing status. 
Table 7. Cluster-adjusted ordered probit regression results for $\mathrm{H} 3$.

\begin{tabular}{|c|c|c|c|c|c|}
\hline \multicolumn{6}{|c|}{$\begin{array}{l}\text { Model 2. } \text { RATING }_{t+1}=\beta_{0}+\beta_{1} D L_{t}+\beta_{2} B_{I G 4_{t}}+\beta_{3} \operatorname{SIZE}_{t}+\beta_{4} L E V_{t}+\beta_{5} L I Q_{t}+\beta_{6} G R W_{t}+\beta_{7} R O A_{t} \\
+\beta_{8} L O S S_{t}+\beta_{9} \Delta C F O_{t}+\beta_{10} L n A G E_{t}+\beta_{11} G R O U P_{t}+\beta_{12} I M R_{t}+\sum I N D+\sum Y D+\varepsilon\end{array}$} \\
\hline \multirow[b]{3}{*}{ Variable } & \multirow[b]{3}{*}{ Pred. Sign } & \multicolumn{4}{|c|}{ Dependent Variable: RATING } \\
\hline & & \multicolumn{2}{|c|}{ Listed Firms } & \multicolumn{2}{|c|}{ Unlisted Firms } \\
\hline & & Coefficient & Wald $X^{2}$-Value & Coefficient & Wald $X^{2}$-Value \\
\hline$D L$ & + & 0.0460 & 0.06 & 0.1378 & 2.38 \\
\hline BIG4 & + & -0.0023 & 0.00 & 0.1413 & 2.34 \\
\hline SIZE & + & 0.0278 & 0.19 & -0.1393 & $9.41^{* * *}$ \\
\hline$L E V$ & - & -7.3377 & $180.22 * * *$ & -6.6268 & $755.64^{* * *}$ \\
\hline$L I Q$ & + & -0.0510 & 0.62 & 0.1643 & $17.64^{* * *}$ \\
\hline$G R W$ & $+/-$ & 0.0886 & 0.19 & -0.0353 & 0.22 \\
\hline$R O A$ & + & 7.2245 & $44.97^{* * *}$ & 8.4582 & $226.80^{* * *}$ \\
\hline LOSS & - & -0.8666 & $22.58^{* * *}$ & -0.7759 & $58.68^{* * *}$ \\
\hline$\triangle C F O$ & + & 1.6748 & $11.49^{* * *}$ & 1.5121 & $73.50 * * *$ \\
\hline $\operatorname{Ln} A G E$ & + & -0.1320 & 1.19 & 0.0480 & 0.64 \\
\hline GROUP & - & 0.2045 & 1.15 & 0.0400 & 0.24 \\
\hline$I M R$ & $+/-$ & -0.0036 & 0.01 & 0.3004 & $29.45^{* * *}$ \\
\hline$\Sigma I N D$ & & & \multicolumn{2}{|c|}{ Included } \\
\hline$\Sigma Y D$ & & \multicolumn{2}{|c|}{ Included } & \multicolumn{2}{|c|}{ Included } \\
\hline Wald $X^{2}$ & & \multicolumn{2}{|c|}{$508.21 * * *$} & \multicolumn{2}{|c|}{$2036.60 * * *$} \\
\hline Pseudo $R^{2}$ & & \multicolumn{2}{|c|}{$53.2 \%$} & \multicolumn{2}{|c|}{$51.8 \%$} \\
\hline $\mathrm{N}$ & & \multicolumn{2}{|c|}{1163} & \multicolumn{2}{|c|}{4970} \\
\hline
\end{tabular}

Notes: Explanatory power and fitness of the ordered probit (cluster-adjusted) regression model are expressed by Pseudo $R^{2}$ and Wald $X^{2}$. ***,** and ${ }^{*}$ denote significance at $1 \%, 5 \%, 10 \%$ levels, respectively (two-tailed). Please refer to Table 2 for variable definitions.

\subsubsection{Main Results: Ordinary Least Square (OLS) Regression Results for H4}

Similar to the previous section, we run Equation (3) over the two subsamples to test Hypothesis 4 and present the results in Table 8. Surprisingly, the coefficient estimate of the test variable $D L$ differs across the two subsamples. The coefficient for the listed firms is statistically insignificant, while that for the unlisted firms is -0.0041 and significant at the $5 \%$ level. This indicates that for unlisted companies, recognizing operating leases in the financial statements can lead to a lower cost of debt than recognizing capital leases. 
Table 8. Cluster-adjusted ordinary least square (OLS) regression results for H4.

\begin{tabular}{|c|c|c|c|c|c|}
\hline \multicolumn{6}{|c|}{ 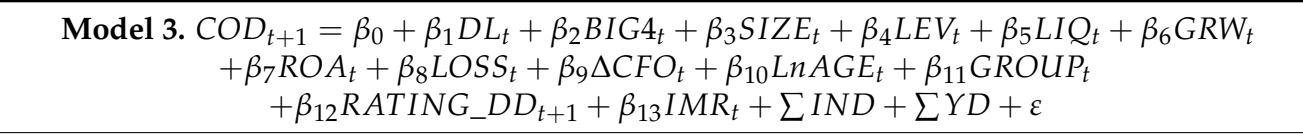 } \\
\hline \multirow[b]{3}{*}{ Variable } & \multirow[b]{3}{*}{ Pred. Sign } & \multicolumn{4}{|c|}{ Dependent Variable: $C O D$} \\
\hline & & \multicolumn{2}{|c|}{ Listed Firms } & \multicolumn{2}{|c|}{ Unlisted Firms } \\
\hline & & Coefficient & $t$-Value & Coefficient & $t$-Value \\
\hline Intercept & $+/-$ & 0.1317 & $4.16^{* * *}$ & 0.0305 & 0.85 \\
\hline$D L$ & - & -0.0008 & -0.20 & -0.0041 & $-2.20 * *$ \\
\hline BIG4 & - & 0.0020 & 0.64 & 0.0006 & 0.32 \\
\hline SIZE & - & -0.0048 & $-3.86^{* * *}$ & 0.0006 & 0.36 \\
\hline$L E V$ & + & 0.0215 & $1.77^{*}$ & 0.0079 & $1.66^{*}$ \\
\hline$L I Q$ & $+/-$ & 0.0030 & $1.70 *$ & 0.0012 & 1.33 \\
\hline GRW & + & 0.0148 & $3.32 * * *$ & 0.0042 & $2.53^{* * *}$ \\
\hline$R O A$ & - & -0.0854 & $-3.99^{* * *}$ & -0.0197 & -1.58 \\
\hline LOSS & + & 0.0037 & 1.05 & -0.0009 & -0.56 \\
\hline$\triangle C F O$ & - & -0.0176 & -1.38 & -0.0028 & -0.84 \\
\hline $\operatorname{Ln} A G E$ & $+/-$ & 0.0047 & $2.33^{* *}$ & -0.0027 & $-2.16^{* *}$ \\
\hline GROUP & + & -0.0007 & -0.18 & 0.0003 & 0.12 \\
\hline RATING_DD & - & -0.0086 & $-1.91 *$ & -0.0038 & $-1.71 *$ \\
\hline$I M R$ & $+/-$ & 0.0014 & 1.49 & -0.0041 & 1.49 \\
\hline$\Sigma I N D$ & & \multicolumn{2}{|c|}{ Included } & \multicolumn{2}{|c|}{ Included } \\
\hline$\Sigma Y D$ & & \multicolumn{2}{|c|}{ Included } & \multicolumn{2}{|c|}{ Included } \\
\hline Adj. $R^{2}$ & & \multicolumn{2}{|c|}{$21.5 \%$} & \multicolumn{2}{|c|}{$12.2 \%$} \\
\hline F Value & & \multicolumn{2}{|c|}{$9.16^{* * *}$} & \multicolumn{2}{|c|}{$18.18^{* * *}$} \\
\hline $\mathrm{N}$ & & \multicolumn{2}{|c|}{1163} & \multicolumn{2}{|c|}{4970} \\
\hline
\end{tabular}

Notes: Explanatory power and fitness of the OLS (cluster-adjusted) regression model are expressed by Adj. $R^{2}$ and $F$-value. ${ }^{* * *},{ }^{* *}$ and ${ }^{*}$ denote significance at $1 \%, 5 \%, 10 \%$ levels, respectively (two-tailed). Please refer to Table 2 for variable definitions.

The results in Table 8 demonstrate that while adoption of operating lease does not cause any change in borrowing interest rates imposed on listed companies, creditors of unlisted firms offer lower interest rates to companies with operating lease when they are not aware that the lease selection is affected by the corporate managers' discretion. This is probably because, unlike listed firms that have properly disclosed financial information, unlisted companies are characterized by severe informational asymmetry; therefore, creditors have difficulty in recognizing companies' opportunistic decisions to choose operating leases over capital leases and are more likely to offer lower interest rates. ${ }^{5}$

\section{Conclusions}

We conduct an empirical analysis of the effect of operating and capital accounting lease options on a company's credit ratings and cost of debt. Typically, companies prefer operating leases to capital leases because, unlike a capital lease, which increases liabilities, an operating lease does not affect liabilities. Thus, it can provide the off-balance-sheet effect, potentially improving credit ratings and lowering the cost of debt. We thus predict that adopting operating leases will enhance credit ratings and reduce the cost of debt.

A firm's listing status can affect its financial and ownership structures. Listed firms can raise capital from the public by issuing stocks or bonds in the open market, while unlisted companies depend mostly on private borrowing for capital (Kim et al. 2011), thereby depending more on debt and being less financially stable than their listed counterparts do. In terms of ownership structure,

5 Results based on the interaction term between lease selection and listing status are similar to those based on subsample analyses. 
listed companies are owned by many shareholders who trade their shares in the market, putting companies under pressure from the capital market and subjecting them to strict regulations regarding disclosure and provision of financial information to investors. On the contrary, unlisted firms are largely family-run businesses and their shares are not traded in the open market (Chaney et al. 2004). Due to these differences in financial and ownership structures, lease selection could have different effects on credit ratings or the cost of debt. Therefore, we also investigate whether recognizing operating leases rather than capital leases influences credit ratings and the cost of debt depending on listing status.

Our major findings are as follows. First, choosing a different lease option does not create a statistically significant effect on credit ratings but selecting an operating lease significantly lowers the costs of debt. This indicates that while credit rating agencies give similar evaluations regardless of lease selection, loan agencies may make different assessments based on the lease option.

Next, listing status does not affect the relationship between lease selection and credit ratings; however, selecting an operating lease lowers the cost of debt only for unlisted companies. This is probably because the same financial experts at credit rating agencies evaluate both listed and unlisted companies, treating the lease selection for both listing statuses equally. On the other hand, companies approach loan agencies with different characteristics based on their listing status. Further, the quantity and quality of financial information available to loan agencies varies by listing status. Therefore, lease selection seemingly has different impacts on the cost of debt according to a firm's listing status.

Although this study provides important empirical evidence on the effect of lease selection on credit rating and cost of debt, it has some limitations. First, this study focuses on Korean firms, due to the availability of data. One of the key questions addressed in this paper is the influence of listing status on the effect of lease selection on credit rating and cost of debt. While it is difficult to get financial data on unlisted firms in many countries, this data for Korean firms are available through KIS VALUE database and the sample in the study is limited to Korea. Thus, it would require additional research to extend our results to firms in other countries in the future. Also, we use several filters which are conventional in research using Korean firms to obtain the final sample. The filter reduces the final sample size considerably compared to the raw sample, which could affect representativeness of our results. Therefore, one should be cautious when applying our results to out-of-sample firms.

This study examines recent data on lease accounting, which has been debated since the introduction of International Financial Reporting Standards (IFRS) and puts forward empirical evidence about the effect of lease selection on credit ratings and the cost of debt. Furthermore, it shows that while credit rating agencies make similar evaluations about companies' lease selection regardless of their listing status, loan agencies consider lease selection differently based on listing status. Our findings could be utilized as vital empirical evidence for further research related to lease accounting and should serve as an important reference for accounting standards that financial institutions or industries follow.

Author Contributions: Y.P. and K.N. conceived and designed the experiments; Y.P. performed the experiments; K.N. analyzed the data; Y.P. and K.N. wrote the paper.

Funding: This research received no external funding.

Acknowledgments: This paper is based on Younghee Park's PhD thesis completed at the Keimyung University. We are grateful to her thesis committee members, Professors Hongbok Ahn, Hyuk Shawn, Indeok Hwang and Seong Hyeon Whang for their helpful comments and guidance.

Conflicts of Interest: The authors declare no conflict of interest.

\section{References}

Abdel-Khalik, Rashad. 1981. The Economic Effects on Leases of FASB Statement No. 13, Accounting for Leases. Norwalk: Financial Accounting Standards Board.

Ball, Ray, and Lakshmanan Shivakumar. 2005. Earnings quality in U.K. private firms: Comparative loss recognition timeliness. Journal of Accounting and Economics 39: 83-128. [CrossRef] 
Becker, Connie. L., Mark L. DeFond, James Jiambalvo, and K. R. Subramanyam. 1998. The effect of audit quality on earnings managements. Contemporary Accounting Research 15: 1-24. [CrossRef]

Burghstahler, David C., Luzi Hail, and Christian Leuz. 2006. The importance of reporting incentives: Earnings management in European public firms. The Accounting Review 814: 983-1016. [CrossRef]

Chaney, Paul K., Debra C. Jeter, and Lakshmanan Shivakumar. 2004. Self-selection of auditors and audit pricing in private firms. The Accounting Review 79: 51-72. [CrossRef]

Chung, Young-Kee. 2000. Operating lease accounting information and equity risk. Korean Journal of Taxation and Accounting 1: 101-24.

Cloyd, Bryan, Jamie Pratt, and Toby Stock. 1996. The use of financial accounting choice to support aggressive tax positions: Public and private firms. Journal of Accounting Research 34: 23-42. [CrossRef]

El-Gazzar, Samir, Steve Lilien, and Victor Pastena. 1986. Accounting for leases by lessees. Journal of Accounting and Economics 8: 217-37. [CrossRef]

Francis, Jennifer, Ryan LaFond, Per Olsson, and Katherine Schipper. 2005. The market pricing of accruals quality. Journal of Accounting and Economics 39: 295-327. [CrossRef]

Ge, Wenxia, and Jeong-Bon Kim. 2013. Real earnings management and the cost of new corporate bonds. Journal of Business Research 67: 641-47. [CrossRef]

Heckman, James. 1979. Sample selection bias as a specification error. Econometrica 47: 153-62. [CrossRef]

Holthausen, Robert, and Richard Leftwich. 1983. The economic consequences of accounting choice: Implications of costly contracting and monitoring. Journal of Accounting and Economics 5: 77-117. [CrossRef]

Hope, Ole-Kristian, Wayne B. Thomas, and Dushyanthumar Vyas. 2013. Financial reporting quality of U.S. private and public firms. The Accounting Review 88: 1715-42. [CrossRef]

Imhoff, Eugene, Robert Lipe, and David Wright. 1991. Operating leases: Impact of constructive capitalization. Accounting Horizons 5: 51-63.

Jeon, Seong-Il, and Ki-Se Lee. 2015. Debt contents and the decision of corporate bond rating. Journal of Accounting and Finance 33: 1-24.

Karjalainen, Jukka. 2011. Audit quality and cost of debt capital for private firms: Evidence from Finland. International Journal of Auditing 15: 88-108. [CrossRef]

Kim, Mong-Tai. 2006. The influence of KOSDAQ firms' earnings management on corporate credit grade. Korean Journal of Business Administration 19: 1689-709.

Kim, Jeong-Bon, Dan A. Simunic, Michael T. Stein, and Cheong H. Yi. 2011. Voluntary audits and the cost of debt capital for privately held firms: Korea evidence. Contemporary Accounting Research 28: 585-615. [CrossRef]

Krishnan, Gopal V. 2003. Audit quality and the pricing of discretionary accruals. A Journal of Practice $\mathcal{E}$ Theory 22: 109-26. [CrossRef]

Kwak, Su-Keun, and Jong-Il Park. 2011. The effect of external auditing on the cost of debt: Focus on privately held firms. Korean Journal of Taxation and Accounting 12: 365-94.

Lee, Joong-Hee. 1999. Economic incentives for lessees' accounting choices. Korean Accounting Review 24: 141-62.

Lee, Sang-Cheol. 2011. A study on the relationship between disclosure quality and cost of debt capital. Korean Accounting Review 20: 1-34.

McGregor, Warren J. 1996. Accounting for Leases: A New Approach: Recognition by Lessees of Assets and Liabilities Arising under Lease Contracts. Norwalk: Financial Accounting Standards Board.

Park, Jong-Il. 2011. The incremental information value of credit ratings on the cost of debt: Focus on non-listed firms. Korean Journal of Taxation and Accounting 12: 523-53.

Park, Jong-Il, and Myung-In Kim. 2013. Earnings management to avoid losses and earnings decreases and the cost of debt: Some empirical evidence on non-listed firms. Korean Accounting Review 38: 283-325.

Park, Young-Hee, and Kyung A. Na. 2017. The effect of listing status on a firm's lease accounting: Evidence from South Korea. Gadjah Mada International Journal of Business 19: 77-92. [CrossRef]

Park, Jong-Il, and Hye-Jeong Nam. 2010. The effect of external audits and the demand for differential audits by non-listed small firms on credit rating: Focus on initial external audited firms. Study on Accounting, Taxation $\mathcal{E}$ Auditing 52: 363-405.

Park, Jong-Il, and Hye-Jeong Nam. 2013. The effect of perceived audit quality of Big-4 on the cost of debt: Some empirical evidence on KOSPI- and KOSDAQ-listed firms. Study on Accounting, Taxation $\mathcal{E}$ Auditing 58: 323-68. 
Park, Jong-Il, and Hye-Jeong Nam. 2014. The effect of perceived audit quality on cost of debt in non-listed firms: Focus on the information and insurance effects of Big-4 auditor choice. Korean Accounting Review 39: $139-87$.

Park, Jong-Il, and Sora Yoon. 2013. Earnings management intervals and means: Comparative study of credit rating and cost of debt. Korean Accounting Review 38: 209-60.

Park, Jong-Il, Kyung-Ho Park, and Chan-Woong Park. 2012. The effect of accrual-based and real earnings management on corporate credit rating: Focus on public and private firms. Korean Journal of Taxation and Accounting 13: 65-98.

Park, Jong-Il, Kyung-Ho Park, and Chan-Woong Park. 2013. The effect of debt dependence on the association between earnings and cost of debt in private firms. Korean Journal of Taxation and Accounting 14: 47-80.

Shawn, Hyuk, and Joong-Hee Lee. 2015. A new perspective on the determinants of lease choice. Korean Accounting Review 40: 105-34.

Teoh, Siew Hong, and T. J. Wong. 1993. Perceived auditor quality and the earnings response coefficient. The Accounting Review 68: 346-66.

Yoon, Tae-Hwa, and Jung-Hwa Hong. 2001. Firm characteristics affecting choice of accounting methods for leases. Korean Journal of Taxation and Accounting 2: 185-206.

(C) 2018 by the authors. Licensee MDPI, Basel, Switzerland. This article is an open access article distributed under the terms and conditions of the Creative Commons Attribution (CC BY) license (http:/ / creativecommons.org/licenses/by/4.0/). 